\title{
Pengaruh Mekanisme Bonus dan Multinationality terhadap Keputusan Transfer Pricing pada Perusahaan Manufaktur di Bursa Efek Indonesia
}

\section{The Effect of Bonus Mechanism and Multinationality on Transfer Pricing Decisions in Manufacturing Companies on the Indonesia Stock Exchange}

\author{
Isra Maulina1), Almira Keumala Ulfah'2) ${ }^{*}$, Heny Rofizar1), Husni Kamal ${ }^{3)}$ \\ \& Muhammad Syafril Nasution ${ }^{3)}$
}

1) Program Studi Akuntansi Syariah, Fakultas Ekonomi Dan Bisnis Islam, IAIN Lhokseumawe, Indonesia

2) Program Studi Hukum Ekonomi Syariah, Fakultas Syariah, IAIN Lhokseumawe, Indonesia 3) Program Studi Perbankan Syariah, Fakultas Syariah, IAIN Lhokseumawe, Indonesia Diterima: 16 Juni 2021; Direview: 02 Agustus 2021; Disetujui: 19 Agustus 2021

*Coresponding Email: almirakeumalaulfah@iainlhokseumawe.ac.id

\section{Abstrak}

Artikel ini bertujuan untuk menguji dan menganalisis Pengaruh Mekanisme Bonus, dan Multinationality Terhadap Keputusan Transfer Pricing Pada Perusahaan Manufaktur Yang Terdaftar di BEI Periode 20162018. Populasi yang digunakan dalam penelitian ini adalah 154 perusahaan manufaktur yang terdaftar di BEI, dan pengambilan sampel menggunakan metode purposive sampling yaitu 25 perusahaan. Teknik pengumpulan data yang digunakan pada penelitian ini yaitu data sekunder. Berdasarkan analisis yang telah dilakukan, hasil penelitian menunjukkan bahwa H1 ditolak. Artinya, mekanisme bonus tidak berpengaruh terhadap transfer pricing. Bonus bukanlah motivator bagi dewan komisaris untuk melakukann transfer pricing, karena pada dasarnya para dewan komisaris sebelum melakukan transfer pricing harus terlebih dahulu mempertimbangkan risiko di bandingkan dengan bonus. H2 ditolak. Artinya, multinationality tidak berpengaruh terhadap transfer pricing. Artinya, tidak semua perusahaan multinasional dapat mengurangi pajaknya dengan melakukan trasfer pricing hal ini di karenakan, jika perusahaan memiliki anak perusahaan di bagian negara yang memiliki pajak yang tinggi maka perusahaan multinasional tidak dapat menurunkan pajaknya dengan alternatif ini.

Kata Kunci: Mekanisme Bonus; Multionality; Tranfer Pricing.

\section{Abstract}

This article aims to examine and analyze the Effect of Bonus Mechanisms, and Multinationality on Transfer Pricing Decisions in Manufacturing Companies Listed on the IDX for the 2016-2018 period. The population used in this study were 154 manufacturing companies listed on the Indonesia Stock Exchange, and the sample was taken using a purposive sampling method, namely 25 companies. The data collection technique used in this research is secondary data. Based on the analysis that has been done, the results show that H1 is rejected. This means that the bonus mechanism has no effect on transfer pricing. Bonuses are not a motivator for the board of commissioners to do transfer pricing, because basically the board of commissioners before doing transfer pricing must first consider the risk compared to the bonus. H2 is rejected. That is, multinationality has no effect on transfer pricing. This means that not all multinational companies can reduce their taxes by doing transfer pricing, this is because, if the company has a subsidiary in a part of the country that has high taxes, the multinational company cannot reduce its taxes with this alternative.

Keywords: Bonus Mechanism; Multionality; Tranfer Pricing.

How to Cite: Maulina, I., Ulfah, A.K., Rofizar, H., Kamal, H., \& Nasution, M.S. (2021). Pengaruh Mekanisme Bonus dan Multinationality terhadap Keputusan Transfer Pricing pada Perusahaan Manufaktur di Bursa Efek Indonesia. Journal of Education, Humaniora and Social Sciences (JEHSS). 4 (2): 127-131. 


\section{PENDAHULUAN}

Globalisasi telah menyebabkan perkembangan ekonomi yang tidak mengenal batas antar suatu negara. Guna melakukan elminasi faktor negatif terhadap batas antar negara, Nurlinda et al (2020) menyatakan bahwa salah satu solusi yang dapat dimanfaatkan oleh perusahaan adalah pemanfaatan perkembangan teknologi informasi. Dengan perkembangan dunia usaha bisnis saat ini, perusahaan-perusahaan nasional kini menjelma menjadi perusahaan-perusahaan multinasional yang kegiatannya tidak hanya berpusat pada satu negara, melainkan di beberapa negara. Sehingga menyebabkan perusahaan untuk melakukan proses produksinya dalam departemen-departemen produksi. Hal ini tidak menjadi sulit apabila hanya terjadi di sebuah perusahaan dalam satu negara karena beban-beban serta biaya yang dikeluarkan akan lebih mudah terukur. Namun, hal ini akan menjadi sulit apabila suatu perusahan memiliki anak perusahaan diberbagai Negara dan itulah yang terjadi saat ini (Khotimah, 2018).

Pada sektor pertambangan, salah satunya pertambangan batu bara, memang menjadi salah satu sektor yang selalu menjadi perhatian khusus bagi pemerintah. Beberapa waktu lalu, sektor pertambangan batu bara kembali diterpa berbagai isu negatif. Isu tersebut mulai dari film dokumenter Sexy Killers yang mengungkap berbagai kerugian dari industri batu bara, laporan indikasi penghindaran pajak Global Witness terhadap salah satu pemain besar batu bara di Indonesia, dukungan pencabutan aturan domestic market obligation, dan berbagai isu lainnya. Komisi Pemberantasan Korupsi (KPK) juga melihat sektor pertambangan ini sektor yang rawan praktik korupsi, salah satunya penghindaran pajak. KPK pernah mencatat kekurangan pembayaran pajak tambang di kawasan hutan sebesar Rp15,9 triliun per tahun. (Novriansa, 2019).

Sinadia (2018) selaku Direktur Eksekutif APBI mengatakan, pemerintah melalui Direktorat Pajak memiliki kewenangan untuk menguji harga pernjualan batubara oleh perusahaan kepada afiliasinya dengan menerapkan "Transfer Pricing Rules" (TP Rules). Yakni melalui mekanisme pemeriksaan pajak. Apabila harga dalam ekspor kepada afiliasinya tidak wajar maka Dirjen Pajak berwenang membuat adjustment dan menagih kekurangan pembayaran PPh. Sinadia menilai, praktik transfer pricing dalam komoditas yang harganya diatur oleh pemerintah seperti di sektor batubara, akan mudah menjadi temuan pajak. Sehingga rasanya pengusaha harus berpikir berkalikali jika ingin memanfaatkan penjualan ke afiliasi hanya untuk mendapatkan keringanan pembayaran PPh. Ia juga mengungkapkan, APBI termasuk yang mendorong penerapan Harga Patokan Batubara (HPB), yang dimaksudkan untuk minimalkan praktik transfer pricing (Sinadia, 2018).

Menurut Sistomo (2017) Praktik transfer pricing dimanfaatkan sebagai perencanaan pajak perusahaan untuk meminimalkan beban pajak yang dibayar melalui rekayasa harga antar perusahaan yang memiliki hubungan istimewa. Beban pajak yang semakin besar memicu perusahaan untuk melakukan praktik transfer pricing dengan harapan dapat menekan beban tersebut. Transfer pricing dalam transaksi penjualan barang atau jasa dilakukan dengan cara memperkecil harga jual antara perusahaan dalam satu grup dan mentransfer laba yang diperoleh kepada perusahaan yang berkedudukan di negara yang menerapkan tarif pajak yang rendah.

Fungsi praktik transfer pricing sudah berkembang, yang awalnya praktik transfer pricing ini hanya digunakan untuk kepentingan tertentu, tetapi saat ini sering dilakukan dengan tujuan yang tidak sesuai dengan tujuan awalnya. Tujuan awal transfer pricing yaitu sebagai penilaian kinerja antar anggota serta devisi perusahaan. Tapi perkembangan zaman telah mampu mengubah fungsi awal transfer pricing. Praktik transfer pricing juga sering digunakan untuk menajemen pajak yaitu sebuah usaha dimana perusahaan mampu meminimalkan jumlah pajak yang harus dibayar. Selain memiliki sifat memaksa, pajak memang merupakan hal yang sering dihindari oleh banyak perusahaan (Mangoting, 2004).

Semakin berkembangnya zaman dengan adanya transfer pricing yang semakin sering digunakan oleh perusahaan untuk memanipulasi sehingga pembayaran pajak yang bisa seminimal mungkin. Tujuan awal dilakukannya transfer pricing semakin hilang karena kesalahan dalam mengaplikasikan dalam suatu perusahaan. Banyak pihak yang beranggapan bahwa transfer 
pricing salah satu penyebab negara akan dirugikan karena pajak yang dibayarkan ternilai kecil (Rahmawati, 2018).

Dalam lingkup perusahaan multinasional, transfer pricing digunakan untuk meminimalkan pajak dan beacukai yang mereka keluarkan diseluruh dunia. transfer pricing dapat menimbulkan beberapa masalah terkait bea cukai, pajak, ketentuan anti dumping, persaingan usaha yang tidak sehat, dan masalah internal manajemen (Rezky dan Fachrizal, 2018).

Transfer pricing biasanya dilakukan oleh perusahaan multinasional, perusahaan multinasional tersebut melihat bahwa bisnis skala global memberikan kesempatan besar untuk berkembang dan juga memperoleh keuntungan yang lebih besar daripada perusahaan yang hanya beroperasi pada skala domestik. Dalam perusahaan multinasional terjadi berbagai transaksi internasional antar anggota (divisi). Beberapa transaksi melibatkan afiliasi yang berada pada dua yurisdiksi berbeda. Perbedaan yurisdiksi dapat menimbulkan masalah, salah satunya adalah masalah tarif pajak yang berbeda setiap negara. Hal itu memicu perusahaan multinasional untuk memperkecil maupun menghindari pajak tinggi juga pajak berganda. Transfer pricing adalah harga yang ditentukan dalam transaksi antar anggota divisi dalam sebuah perusahaan multinasional, dimana harga transfer yang ditentukan tersebut dapat menyimpang dari harga pasar dan cocok antar divisinya (Suandy, 2011).

Menurut Rusli (2017) transfer pricing adalah harga yang ditentukan dalam transaksi antar anggota divisi dalam sebuah perusahaan multinasional, dimana harga transfer yang ditentukan tersebut dapat menyimpang dari harga pasar dan cocok antar divisinya, dalam prakteknya transfer pricing digunakan oleh beberapa perusahaan multinasional untuk menghindari pungutan pajak yang besar dengan cara mengecilkan pajaknya dan membuat beberapa Negara mengalami kerugian dalam penerimaan pajak.

Keputusan untuk melakukan transfer pricing di pengaruhi oleh mekanisme bonus. Mekanisme bonus merupakan komponen perhitungan bonus melalui RUPS kepada anggota direksi yang besarnya bonus diberikan oleh pemilik atau pemegang saham yang memiliki kinerja baik setiap tahun dan apabila perusahaan memperoleh laba. Mekanisme dapat digunakan sebagai ukuran apabila suatu perusahaan tersebut memiliki laba. Mekanisme bonus berdasarkan besarnya laba akan membuat direksi berupaya untuk melakukan manipulasi laba bahkan juga dilakukan manipulasi laba bersih dengan tujuan mampu memaksimalkan bonus diterimanya. Dalam mekanisme bonus ini juga bisa menimbulkan kecurangan yang bersifat menguntungkan pribadi (Indriaswari, 2017).

\section{METODE PENELITIAN}

Populasi adalah wilayah generalisasi yang terdiri atas: objek/subjek yang mempunyai kualitas dan karakteristik tertentu yang ditetapkan oleh peneliti untuk dipelajari dan kemudian ditarik kesimpulannya (Sugiyono, 2015). Populasi yang digunakan dalam penelitian ini adalah perusahaan-perusahaan manufaktur yang terdaftar di Bursa Efek Indonesia (BEI) selama periode 2016-2018 yang terdiri dari 154 perusahaan.

Sampel adalah bagian dari jumlah dan karakteristik yang dimiliki oleh populasi tersebut (Sugiyono, 2015). Pengambilan sampel di dalam penelitian ini menggunakan teknik purposive sampling. Teknik purposive sampling adalah teknik penentuan sampel dengan pertimbangan tertentu (Sugiyono, 2015). Alasan menggunakan teknik purposive sampling karena tidak semua sampel memiliki kriteria yang sesuai dengan fenomena yang dimiliki. Oleh karena itu, penulis memilih teknik purposive sampling yang menetapkan kriteria-kriteria tertentu yang harus dipenuhi oleh sampel yang digunakan dalam penelitian ini.

Adapun kriteria-kriteria yang dijadikan sebagai sampel dalam penelitian ini adalah: 1) Perusahaan manufaktur yang terdaftar di BEI pada tahun 2016-2018; 2) Perusahaan manufaktur yang menyediakan annual report tahun 2016-2018; 3) Perusahaan yang tidak mengalami kerugian dalam tahun penelitian; 4) Perusahaan sampel memiliki anak perusahaan dan/atau perusahaan afiliasi diluar negeri.

Berdasarkan metode di atas, diperoleh populasi 154 perusahaan manufaktur yang terdaftar di Bursa Efek Indonesia, yaitu mulai tahun 2016 hingga tahun 2018. Dengan adanya kriteria12.48 http://mahesainstitute.web.id/ojs2/index.php/jehss v1 mahesainstitut@gmail.com

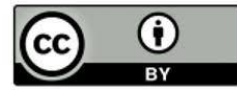


kriteria yang dibutuhkan maka diperoleh 25 perusahaan yang diteliti selama 3 periode, sehingga sampel yang dapat digunakan sebanyak 75 pengamatan.

Teknik pengumpulan data merupakan langkah yang paling strategis dalam penelitian, karena tujuan utama dari penelitian adalah mendapatkan data (Sugiyono, 2015). Teknik pengumpulan data yang digunakan pada penelitian ini yaitu data sekunder. Data sekunder adalah data yang diperoleh peneliti dari sumber yang sudah ada. Maka teknik pengumpulan data yang dilakukan pada penelitian ini adalah teknik dokumentasi dan teknik studi pustaka.

Menurut Sukardi (2003), teknik dokumentasi digunakan oleh peneliti untuk memperoleh informasi dari bermacam-macam sumber tertulis atau dokumen yang ada pada responden atau tempat responden bertempat tinggal atau melakukan kegiatan sehari-hari. Metode dokumentasi dilakukan dengan cara menelusuri yang dilakukan dengan mengumpulkan data sekunder yaitu dengan cara mengumpulkan, mencatat, dan mengkaji data sekunder yang berupa laporan keuangan perusahaan manufaktur yang terdaftar di Bursa Efek Indonesia pada tahun 2016 -2018 secara berturut-turut. Sumber data di dapat dari www.idx.co.id atau website resmi perusahaan.

Studi pustaka merupakan sebuah metode yang digunakan untuk mendapatkan informasi data secara teoritis melalui buku-buku dan bahan tertulis lainnya yang berkaitan dengan penelitian guna memperoleh landasan dalam mengelolah data dan dapat menarik kesimpulan.

\section{HASIL DAN PEMBAHASAN \\ Uji Asumsiklasik \\ Uji Normalitas}

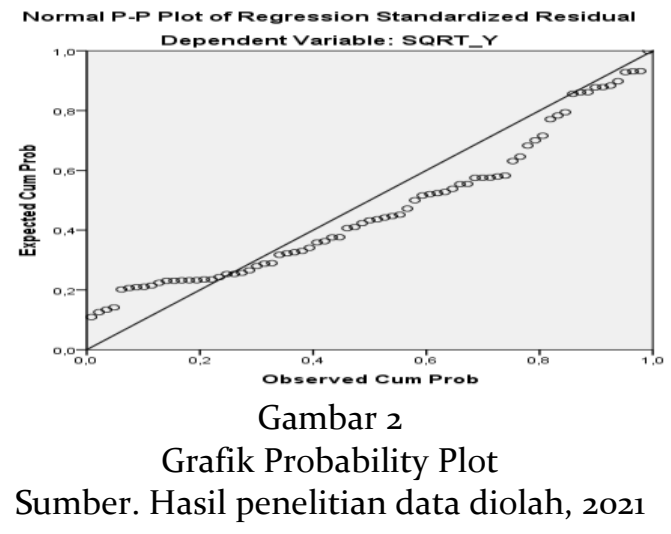

Pada prinsipnya normalitas dapat di deteksi dengan melihat penyebaran (titik) pada sumbu diagonal dari grafik. Bentuk data terdistribusi normal secara normal akan mengikuti pola distribusi normal dimana datanya mengikuti garis diagonal. Pada gambar di atas dapat di lihat bahwa data menyebar di sekitar garisgaris diagonal dan mengikuti arah garis diagonal. Maka model regresi memenuhi asumsi normalitas.

Tabel 3

Uji Normalitas (Kolomogorov Smirnov)

One-Sample Kolmogorov-Smirnov Test

\begin{tabular}{|c|c|}
\hline & Unstandardized Residual \\
\hline \begin{tabular}{l} 
N \\
Normal $\quad$ Mean \\
Parametersa,bStd. Deviation \\
Most ExtremeAbsolute \\
Differences $\quad$ Positive \\
\multicolumn{1}{c}{ Negative } \\
Test Statistic \\
Asymp. Sig. (2-tailed)
\end{tabular} & $\begin{array}{l}62 \\
\text {,ooooooo } \\
2,00846357 \\
, 104 \\
, 082 \\
-, 104 \\
, 104 \\
, 096 c\end{array}$ \\
\hline
\end{tabular}


a. Test distribution is Normal.

b. Calculated from data.

c. Lilliefors Significance Correction.

Sumber: Hasil Penelitian, Data diolah 2021

Jika nilai Asymp. Sig. (2-tailed) lebih besar dari 0,05 maka data residual berdistribusi normal. Sebaliknya jika Asymp. Sig. (2-tailed) lebih kecil dari 0,05 maka data tersebut tidak terdistribusi normal. Uji normalitas pada tabel 4.3 diatas dapat diketahui bahwa Asymp. Sig. (2-tailed) sebesar 0,096 lebih besar dari 0,05. Maka dapat disimpulkan bahwa model regresi berdistribusi normal.

\section{Uji Multikolonieritas}

Tabel 4

Uji Multikolonieritas

Coefficients $^{\mathrm{a}}$

\begin{tabular}{|c|c|c|c|c|c|}
\hline \multirow[b]{2}{*}{ Model } & \multicolumn{2}{|c|}{ Unstandardized Coefficients } & \multirow{2}{*}{\begin{tabular}{|l} 
Standardized Coefficients \\
Beta
\end{tabular}} & \multicolumn{2}{|c|}{ Collinearity Statistics } \\
\hline & B & Std. Error & & Tolerance & VIF \\
\hline $1 \quad$ (Constant) &, 866 &, 315 & & & \\
\hline Mekanisme Bonus & $-4,019 \mathrm{E}-6$ & ,ooo &,- 040 & ,948 & 1,054 \\
\hline Multinationality &,- 007 &, 251 &,- 004 &, 806 & 1,241 \\
\hline
\end{tabular}

a. Dependent Variable: transfer pricing

Sumber : Data primer yang diolah 2021

Berdasarkan data pada tabel 4.4 di atas, dapat dilihat hasil perhitungan nilai tolerance dan VIF. Nilai tolerance untuk variabel mekanisme bonus $\left(\mathrm{X}_{1}\right)$ sebesar $0,948>0,05$ dan VIF sebesar $1,054<5$ sehingga mekanisme bonus tidak terjadi multikolinearitas. Untuk variabel multinationality $\left(\mathrm{X}_{2}\right)$ nilai tolerance sebesar $0,806>0,05$ dan nilai VIF sebesar $1.241<5$ maka Lokasi multinationality tidak terjadi multikolinearitas.

\section{Uji Heteroskedastisitas}

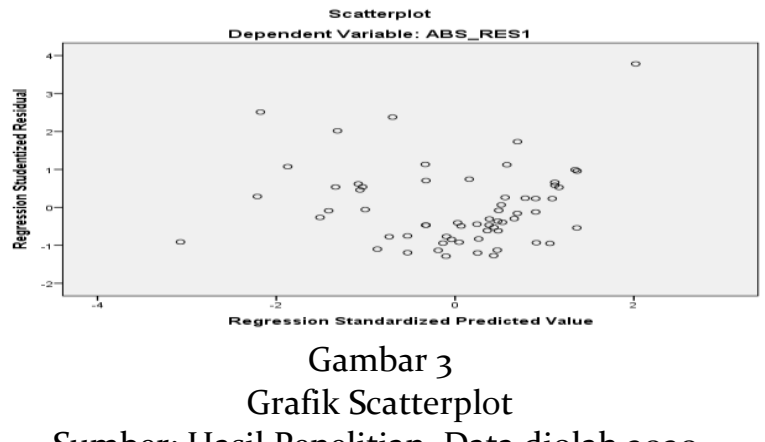

Sumber: Hasil Penelitian, Data diolah 2020.

Berdasarkan hasil uji heteroskedastisitas pada Grafik scatter plot menunjukkan bahwa titiktitik menyebar secara acak diatas maupun dibawah angka 0 pada sumbu Y. Hal ini dapat disimpulkan bahwa tidak terjadi heteroskedastisitas pada model regresi, sehingga model regresi layak dipakai untuk memprediksi transfer pricing berdasarkan masukan variabel independen mekanisme bonus, tunneling incentive dan multinationality.

\section{Uji Autokorelasi}

Tabel 5

Uji Autokorelasi

Model Summaryb

\begin{tabular}{l} 
Model Summaryb \\
\begin{tabular}{|l|l|l|l|l|l|}
\hline Model & R & R Square & Adjusted R Square & Std. Error of the Estimate & Durbin-Watson \\
\hline 1 & ,o12a & ,ooo &,- 014 &, 95740919 & 1,999 \\
\hline
\end{tabular} \\
\hline
\end{tabular}


a. Predictors: (Constant), Lag_Resı

b. Dependent Variable: Transfer Pricing

Sumber.Hasil Penelitian Data Diolah, 2020

Berdasarkan tabel 4.5 nilai Durbin Watson menunjukkan nilai 1,999 nilai dU sebesar 1,543 dan 4-dU sebesar 2,457. Jadi nilai dU 1,543 < DW 1,999 < 4-dU 2,457 sehingga, dapat disimpulkan tidak ada terjadi autokorelasi pada regresi linier berganda.

\section{Uji Hipotesis}

\section{Analisis Regresi Berganda}

Tabel 6

Hasil Analisis Regresi

\begin{tabular}{|c|c|c|c|c|c|}
\hline \multicolumn{6}{|l|}{ Coefficients $^{\mathrm{a}}$} \\
\hline \multirow[b]{2}{*}{ Model } & \multicolumn{2}{|c|}{$\begin{array}{l}\text { Unstandardized } \\
\text { Coefficients }\end{array}$} & \multirow{2}{*}{\begin{tabular}{|l} 
Standar \\
dized \\
Coeffici \\
ents
\end{tabular}} & \multirow[b]{2}{*}{$t$} & \multirow[b]{2}{*}{ Sig. } \\
\hline & B & $\begin{array}{l}\text { Std. } \\
\text { Error }\end{array}$ & & & \\
\hline 1 (Constant) & 866 & 315 & & 2,749 &, 008 \\
\hline $\begin{array}{l}\text { Mekanism } \\
\text { e Bonus }\end{array}$ & $-4,019 E-6$ & ,ooo &,- 040 &,- 340 &, 735 \\
\hline $\begin{array}{l}\text { Multinatio } \\
\text { nality }\end{array}$ &,- 007 & 251 &,- 004 &,- 029 & ,977 \\
\hline
\end{tabular}

a. Dependent Variable: transfer pricing

Sumber : hasil penelitian data diolah 2020

Berdasarkan tabel 4.6 hasil perhitungan dari uji regresi linier berganda diperoleh nilai kostanta (a) dari model regresi $=0.866$ dan koefisien regresi (b) dari setiap variabel-variabel independen diperoleh $b_{1}=-4,019 E-6 b_{2}=-, 679$ dan $b_{3}=-, 007$. Berdasarkan nilai konstanta dan koefisien regresi tersebut, maka hubungan antara variabel-variabel independen dengan variabel dependen dalam model regresi dapat dirumuskan sebagai berikut :

$\mathrm{Y}=0.886-4,019\left(\mathrm{X}_{1}\right)-0,007\left(\mathrm{X}_{2}\right)$

Dari Persamaan di atas dapat dijelaskan sebagai berikut:

1. Nilai konstanta (a) adalah 0.866. Artinya jika variabel tunneling incentive, mekanisme bonus dan multinationalitu dianggap konstan (bernilai 0), maka nilai transfer pricing adalah sebesar 0.866 atau $86.6 \%$

2. Untuk nilai koefisien regresi variabel mekanisme bonus $\left(\mathrm{X}_{1}\right)$ bernilai -4,019E-6. Hal ini menunjukkan bahwa adanya hubungan negatif terhadap transfer pricing. setiap peningkatan mekanisme bonus sebesar 1\%, maka akan meningkatkan transfer pricing sebesar -4,019E-6. semakin tinggi persentase mekanisme bonus maka persentase transfer pricing semakin menurun.

3. Untuk nilai koefisien regresi variabel multinationality $\left(\mathrm{X}_{2}\right)$ bernilai sebesar 0,007 . hal ini menunjukkan adanya hubungan negatif terhadap transfer pricing. setiap peningkatan multinationality sebesar 1\%, maka akan menurunkan transfer pricing sebesar 0,007 atau 0,7\%. semakin tinggi persentase multinationality maka persentase transfer pricing semakin menurun atau tetap. 


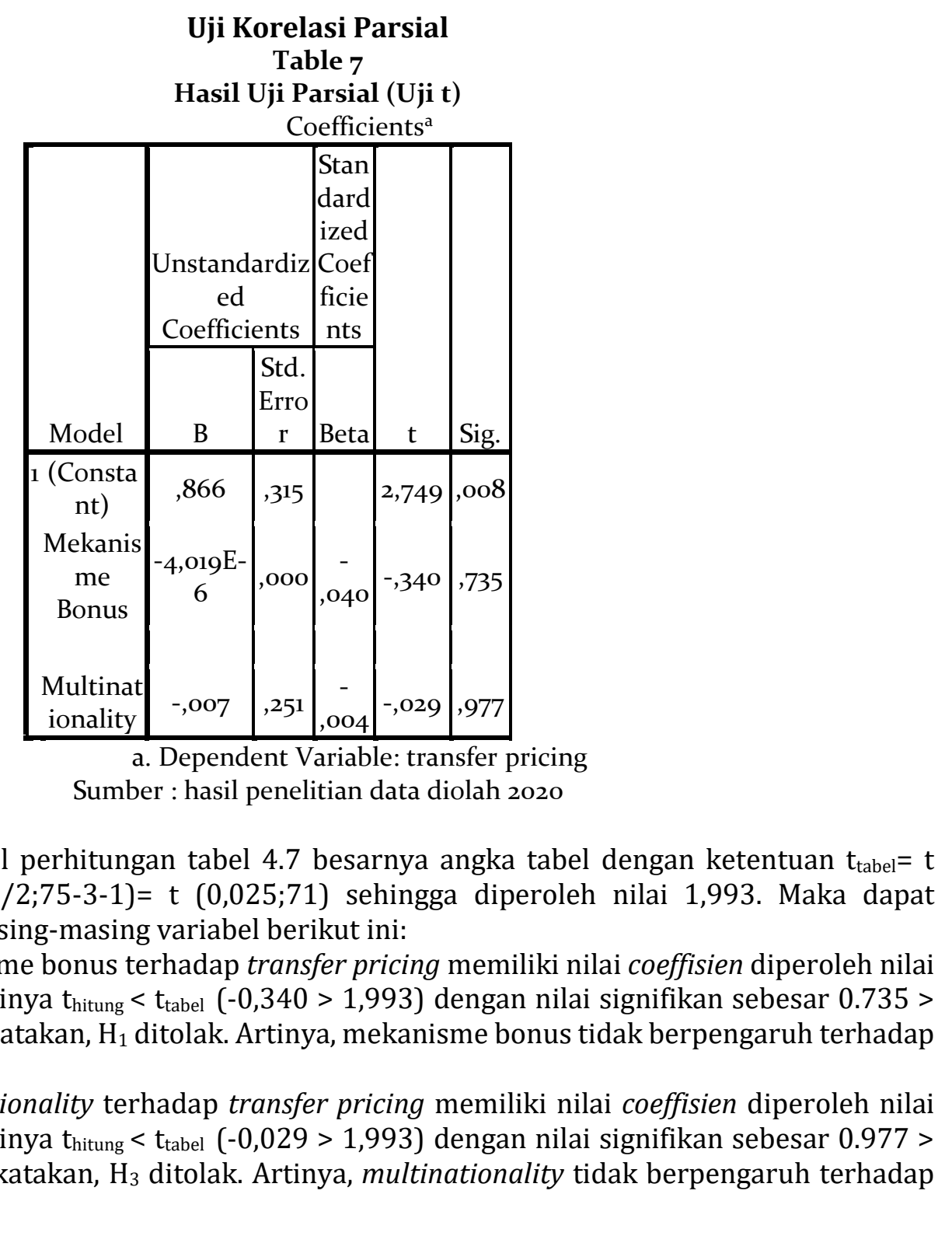

Uji Koefisien Determinasi $\left(R^{2}\right)$

Tabel 8

Hasil Uji Koefisien Determinasi R2 Model Summary

\begin{tabular}{|l|l|l|l|l|}
\hline Model & R & R Square & Adjusted R Square & Std. Error of the Estimate \\
\hline 1 &, $259 \mathrm{a}$ &, 067 &, 028 &, 40343 \\
\hline
\end{tabular}

a. Predictors: (Constant), multinationality, mekanisme bonus, tunneling incentive Sumber : Hasil penelitian, Data diolahi 2020

Koefisien determinasi digunakan untuk melihat seberapa besar variabel independen dapat menjelaskan variasi variabel dependen. Adjusted R Square bernilai 0.028, menunjukkan bahwa kemampuan variabel-variabel independen (mekanisme bonus, tunneling incentive, dan multinationality) dalam menjelaskan variasi variabel dependen (transfer pricing) yaitu sebesar $2,8 \%$, sedangkan sisanya disebabkan oleh variabel lain yang tidak terdapat di dalam penelitian ini. 
Nilai koefisien determinasi tersebut cukup kecil (kurang dari 50\%). Berarti kemampuan variabel independen dalam menjelaskan variasi dependen di dalam penelitian ini cukup terbatas.

Keterangan gambar/grafik diletakkan di bawah gambar/grafik tersebut, sedangkan judul tabel diletakkan di atas tabelnya. Judul diawali dengan huruf kapital. Jangan mengulang menulis angka-angka yang telah tercantum dalam tabel di dalam teks pembahasan. Jika akan menekankan hasil yang diperoleh sebaiknya sajikan dalam bentuk lain, misalnya persentase atau selisih. Untuk menunjukkan angka yang dimaksud, rujuk saja tabel yang memuat angka tersebut.

Pada umumnya jurnal internasional tidak menginginkan bahasa statistik (seperti: significantly different, treatment, dll) ditulis dalam pembahasan. Hindari copy dan paste tabel hasil analisis statistik langsung dari software pengolah data statistik.

Dalam menuliskan table, Sesuaikan dengan panduan penulisan, yaitu memakai open tabel saja, table yang tidak menggunakan memakai garis vertical. Seperti contoh di bawah ini.

\section{Pengaruh Mekanisme bonus terhadap Transfer Pricing}

Pengujian variabel mekanisme bonus (X1) terhadap transfer pricing (Y) di peroleh nilai thitung $-0,735$ yang artinya thitung $<$ ttabel $(-0,735>1,993)$ dengan nilai signifikan sebesar 0.735 $>0,05$ sehingga dapat dikatakan, H1 ditolak. Artinya, mekanisme bonus tidak berpengaruh terhadap transfer pricing.

Bonus bukanlah motivator bagi dewan komisaris untuk melakukann transfer pricing, karena pada dasarnya para dewan komisaris sebelum melakukan transfer pricing harus terlebih dahulu mempertimbangkan risiko di bandingkan dengan bonus. Hasil penelitian ini berkaitan dengan teori earnings retention Masalah ini berkaitan dengan kecenderungan untuk melakukan investasi yang berlebihan oleh pihak manajemen (agen) melalui peningkatan dan pertumbuhan dengan tujuan untuk memperbesar kekuasaan, prestise, atau penghargaan bagi dirinya, namun dapat menghancurkan kesejahteraan pemegang saham (Colgan, et alt,2012).

Penelitian ini mendukung penelitian yang di lakukan oleh (Meriana dan Tumewu, 2018) yang pada hasil penelitiannya menyatakan Variabel mekanisme bonus tidak selalu menjadikan motivator bagi dewan direksi untuk melakukan keputusan transfer pricing. Besarnya kompensasi/bonus bukan merupakan motivasi utama bagi dewan direksi untuk melakukan keputusan transfer pricing.

\section{Pengaruh Multinationality terhadap Trasfer Pricing}

Pengujian variabel multinationality (X2) terhadap transfer pricing (Y) di peroleh nilai thitung $-0,029$ yang artinya thitung $<$ ttabel $(-0,029>1,993)$ dengan nilai signifikan sebesar 0.977 $>0,05$ sehingga dapat dikatakan, $\mathrm{H} 2$ ditolak. Artinya, multinationality tidak berpengaruh terhadap transfer pricing.

Artinya, tidak semua perusahaan multinasional dapat mengurangi pajaknya dengan melakukan trasfer pricing hal ini di karenakan, jika perusahaan memiliki anak perusahaan di bagian negara yang memiliki pajak yang tinggi maka perusahaan multinasional tidak dapat menurunkan pajaknya dengan alternatif ini.

Hasil penelitian ini berkaitan dengan teori akuntansi positif yang tujuannya adalah motivasi pajak, berdasarkan teori political cost pemerintah akan mewajibkan suatu perusahaan untuk membayar pajak yang sesuai dengan laba yang di dapat perusahaan, sehingga hal ini tentunya membuat perusahaan merasa mendapatkan tekanan karena harus secara rutin membayar pajak kepada negara yang dapat membuat laba perusahaan menurun. Maka dari itu manager perusahaan akan cenderung untuk memilih melakukan transfer pricing ke grup perusahaannya yang ada di negara lain agar pajak yang dibayar oleh perusahaan bisa seminimal mungkin. Beban pajak yang akan dibayarkan perusahaan akan semakin kecil dan pendapatan perusahaan pun akan tetap meningkat (Aurinda, 2018). Hasil penelitian ini menolak penelitian yang di lakukan oleh (Aprilia dan Fachrizal, 2018) yang dalam penelitiannya menyatakan multinationality berpengaruh terhadap keputusan transfer pricing. Hal ini mengkonfirmasi bahwa perusahaan multinasional berperan dalam keputusan transfer pricing.. 


\section{SIMPULAN}

Hasil pengujian statistik menunjukkan bahwa mekanisme bonus tidak berpengaruh terhadap keputusan transfer pricing karena bonus bukanlah motivator bagi dewan komisaris untuk melakukan transfer pricing, karena pada dasarnya para dewan komisaris sebelum melakukan transfer pricing harus terlebih dahulu mempertimbangkan risiko di bandingkan dengan bonus. Hasil pengujian statistik menunjukkan bahwa multinationality tidak berpengaruh terhadap trasnfer pricing, artinya tidak semua perusahaan multinasional dapat mengurangi pajaknya dan melakukan transfer pricing di karenakan, jika perusahaan memiliki anak perusahaan di bagian negara yang memiliki pajak yang tinggi maka perusahaan multinational tidak dapat menurunkan pajaknya dengan alternatif ini..

\section{DAFTAR PUSTAKA}

Ananta, M. C. A. (2018). Analisis Pengaruh Pajak, Multinasionalitas, Ukuran Perusahaan, Dan Profitabilitas Terhadap Praktik Transfer Pricing (Studi Empiris Pada Perusahaan Manufaktur Yang Terdaftar di Bursa Efek Indonesia Tahun 2014-2016).

Aurinda. (2018). Analisis Faktor-faktor Yang Mempengaruhi Keputusan Perusahaan untuk Melakukan Transfer Pricing. Skripsi Fakultas Ekonomi dan Bisnis Universitas Lampung.

Azzura, C. S., \& Pratama, A. (2019). Influence of Taxes, Exchange Rate, Profitability, and Tunneling Incentive on Company Decisions of Transferring Pricing. Jurnal Akuntansi Berkelanjutan Indonesia, 2(1), 123.

Colgan, P. Mc. (2012). Agency Theory and Corporate Governance: A Review of the Literature From a UK Perspective. Working paper University of Strathclyde at United Kingdom.

Ghozali, I, (2016), Aplikasi Analisis Multivariate dengan Program SPSS, Semarang: BP Undip

Hartati, W., \& Desmiyati, J. (2015). Tax Minimization, Tunneling Incentive dan Mekanisme Bonus terhadap Keputusan Transfer Pricing Seluruh Perusahaan yang Listing di Bursa Efek Indonesia. Jurnal SNA, 18.

Hidayat, W., dan Hendrawan. (2019). Pengaruh pajak dan Tunneling Incentive Terhadap Keputusan Transfer Pricing Pada Perusahaan Pertambangan yang Terdaftar di Bursa Efek Indonesia (BEI) Periode 2012

Hidayat, D. W. W., Winarso, W., \& Hendrawan, D. Peer Review Pengaruh Pajak dan Tunneling Incentive Terhadap Keputusan Transfer Pricing Pada Perusahaan Pertambangan yang terdaftar di Bursa Efek Indonesia (BEI) Periode 2012-2017.

Horngren, T, Charles, Srikant M, Datar, dan George Foster. (2008). Akuntansi Biaya: Dengan Penekanan Manajerial.. Jakarta: Erlangga.

Indriaswari, A. (2017). The influence of tax, tunneling incentive, and bonus mechanisms on transfer pricing decision in manufacturing companies. The Indonesian Accounting Review, 7 (1), 69 - 78.

Khotimah, S. K. (2019). Pengaruh beban pajak, tunneling incentive, dan ukuran perusahaan terhadap keputusan perusahaan dalam melakukan transfer pricing (Studi empiris pada perusahaan multinasional yang listing di Bursa Efek Indonesia tahun 2013-2017). Jurnal Ekobis Dewantara, $1(12), 125-138$.

Lo, W. Y. A., M. K. W. Raymond, dan F. Micheal. (2010). Tax, Financial Reporting, and Tunneling Incentives for Income Shifting: An Empirical Analysis of the Transfer Pricing Behavior of ChineseListed Companies. Journal of the American Taxation Association, 32(2): 1-26.

Lumbantoruan, S. (2000) Akuntansi Pajak, Edisi Revisi, Jakarta. Grasindo

Mangoting, Y. (2004). Aspek Perpajakan dalam Praktek Transfer pricing. Jurnal Akuntansi dan Keuangan 2 (1): 69-82.

Melda, S., Nadilla, T., Ramadhan, R., Iskandar, I., Ridha, A., \& Puspita, D. (2020, February). Pengaruh Earning Power dan Perubahan Tarif Pajak Terhadap Manajemen Laba Pada Perusahaan Perbankan yang telah Go Public di Bursa Efek Indonesia. In Seminar Nasional Teknologi Komputer \& Sains (SAINTEKS) (Vol. 1, No. 1, pp. 646-648).

Melmusi, Z. (2016). Pengaruh pajak, mekanisme bonus, kepemilikan asing dan ukuran perusahaan terhadap transfer pricing pada perusahaan yang tergabung dalam Jakarta Islamic Index dan terdaftar di Bursa Efek Indonesia Periode 2012-2016. Jurnal Ekobistek, 5(2).

Mutamimah, M. (2009). Tunneling Atau Value Added Dalam Strategi Merger Dan Akuisisi Di Indonesia. Jurnal Manajemen Teori dan Terapan, 2(2).

Nazihah, A., \& Fuadah, L. L. (2019). The effect of tax, tunneling incentive, bonus mechanisms, and firm size on transfer pricing (Indonesian evidence).

Nadilla, T., Ulfah, A. K., Hayati, H., Midesia, S., \& Puspita, D. (2019, November). The Effect Of Leverage And Earning Per Share On Earning Management (A Study Of Companies Listed In Indonesia Stock

12.54 http://mahesainstitute.web.id/ojs2/index.php/jehss

vinahesainstitut@gmail.com

1254

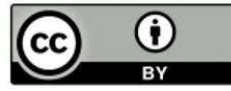

This work is licensed under a Creative Commons Attribution 4.0 
Exchange). In ICASI 2019: Proceedings of The 2nd International Conference On Advance And Scientific Innovation, ICASI 2019, 18 July, Banda Aceh, Indonesia (p. 164). European Alliance for Innovation.

Nurlinda, N., Napitupulu, I., Wardayani, W., Azlina, A., Andina, A., Ulfah, A., \& Supriyanto, S. (2020). Can ECommerce Adoption Improve SME's Performance?(Case Studies on Micro, Small and Medium Enterprises with Gojek Services in Indonesia).

Novriansa. A. (2019). Sektor Pertambangan Rawan Manipulasi Transfer Pricing?. DDTCNews. 14 Oktober 2019. Dikutip 5 Desember 2019.

Nugraha, A. K. (2016). Analisis Pengaruh Beban Pajak, Tunneling Incentive, Dan Mekanisme Bonus Terhadap Transfer Pricing Perusahaan Multinasional Yang Listing Di Bursa Efek Indonesia (Doctoral dissertation, UNIVERSITAS NEGERI SEMARANG).

Rahmawati, E. Y. (2018). Pengaruh Pajak, Tunneling Incentive, dan Mekanisme Bonus Terhadap Keputusan Transfer Pricing (Perusahaan Sektor Dasar dan Kimia yang Terdaftar di BEI Periode 2013-2016) (Doctoral dissertation, Universitas Muhammadiyah Sidoarjo).

Razali, R. (2020). Perilaku Konsumen: Hedonisme dalam Perspektif Islam. Jurnal Ekonomi Syariah, Akuntansi Dan Perbankan (JESKaPe), 4(1), 115-124.

Refgia, T., Ratnawati, V., \& Rusli, R. (2017). Pengaruh pajak, mekanisme bonus, ukuran perusahaan, kepemilikan asing, dan tunneling incentive terhadap transfer pricing (perusahaan sektor industri dasar dan kimia yang listing di bei tahun 2011-2014) (Doctoral dissertation, Riau University).

Rego, S. O. (2003). Tax-avoidance activities of US multinational corporations. Contemporary Accounting Research, 20(4), 805-833.

Rezky, F. (2018). Pengaruh Mekanisme Bonus, Ukuran Perusahaan, Leverage dan Multinationality Terhadap Keputusan Transfer Pricing Pada Perusahaan Manufaktur yg Terdaftar di Bursa Efek Indonesia tahun 2010-2014. Jurnal Ilmiah Mahasiswa Ekonomi Akuntansi (JIMEKA), 3 (3), 401-415.

Refgia, T., Ratnawati, V., \& Rusli, R. (2017). Pengaruh pajak, mekanisme bonus, ukuran perusahaan, kepemilikan asing, dan tunneling incentive terhadap transfer pricing (perusahaan sektor industri dasar dan kimia yang listing di bei tahun 2011-2014) (Doctoral dissertation, Riau University).

Saifudin, S., \& Putri, S. (2018). Determinasi Pajak, Mekanisme Bonus, dan Tunneling Incentive terhadap Keputusan Transfer Pricing pada Emiten BEI. Agregat: Jurnal Ekonomi dan Bisnis, 2(1), 32-43.

Santosa, S. J. D., \& Suzan, L. (2018). Pengaruh Pajak, Tunneling Incentive dan Mekansme Bonus Terhadap Keputusan Transfer Pricing (Studi Kasus pada Perusahaan Sektor Industri Barang Konsumsi yang Terdaftar di Bursa Efek Indonesia Tahun 2013-2016). Kajian Akuntansi, 19(1), 72-80.

Saraswati, G. A. R. S., \& Sujana, I. K. (2017). Pengaruh pajak, mekanisme bonus, dan tunneling incentive pada indikasi melakukan transfer pricing. E-Jurnal Akuntansi Universitas Udayana, 19(2), 1000-1029.

Setiawan, H. (2014). Transfer pricing dan risikonya terhadap penerimaan negara. Diakses dari http://kemekeu. go. id.

Sinadia. H. (2018). Soal Transfer Pricing Batubara, APBI: Nampaknya Pengusaha Harus Berpikir Berkali-kali. Kontan.co.id, 28 Juli 2018. Dikutip 5 Desember 2019.

Suandy, E. (2011). Perencanaan Pajak, Edisi 4. Jakarta: Salemba Empat.

Sugiyono. (2015). Metode Penelitian Kuantitatif, Kualitatif, dan R \& D , Edisi ke-15. Bandung: Alfabeta.

Sukardi. (2003). Metodologi Penelitian Pendidikan. Yogyakarta: Bumi Aksara.

Ulfah, A.K, et al. (2020), Accounting Equations in Business Transactions. Psychology and Education Journal 57.8 (2020): 456-460.

Wijaya, B., \& Kusuma, H. (2017). Drivers of the Intensity of Transfer Pricing: An Indonesian Evidence. مؤتمر ات التجارة كلية

Ulfah, A.K, et al. (2020), Accounting Equations in Business Transactions. Psychology and Education Journal 57.8 (2020): 456-460. 